Т. В. Мелкумова

\title{
ВИВЧЕННЯ КАТЕГОРІЙ ВИДУ ТА ЧАСУ ДІССЛІВ НА ЗАНЯТТЯХ 3 УКРАЇНСЬКОЇ МОВИ ЯК ІНОЗЕМНОЇ НА І КУРСІ
}

Мелкумова Т. В. Вивчення категорій виду та часу дієслів на заняттях 3 української мови як іноземної на I курсі.

У статті подано методику вивчення часових форм дієслів доконаного та недоконаного видів на заняттях зі студентами-іноземцями I курсу всіх спеціальностей. Запропоновано низку завдань для актуалізації, поглиблення, систематизації, узагальнення та закріплення знань іноземних студентів про видові та часові форми дієслів.

Ключові слова: дієслово, інфінітив, доконаний вид, недоконаний вид, час дієслова. 
Мелкумова Т. В. Изучение категорий вида и времени глаголов на занятиях по украинскому языку как иностранному на I курсе.

В статье подана методика изучения временных форм глаголов совершенного и несовершенного видов на занятиях со студентами-иностранцами I курса всех специальностей. Предложена серия заданий для актуализации, углубления, систематизации, обобщения и закрепления знаний иностранных студентов про виды и времена глаголов.

Ключевые слова: глагол, инфинитив, совершенный вид, несовершенный вид, время глагола.

Melkumova T. W. Studying of tense and aspect verb categories on Ukrainian as foreign language lessons for the first-year students.

The article deals with the methods of study tense verb forms of perfect and imperfect aspects on Ukrainian lessons with first-year foreign students of all specialties. The kinds of exercises for actualization, intensification, systematization, generalization, consolidation of foreign students' knowledge about tense and aspect verb categories are proposed.

Key words: verb, infinitive, perfect aspect, imperfect aspect, tense of verb.

Мовна підготовка іноземців, що навчаються в українських вищих навчальних закладах, поєднує три взаємопов'язані складники. Мовний змістовий складник уключає основні мовні одиниці, поняття, факти, закономірності, що забезпечують обсяг знань, оптимальний для формування мовленнєвих умінь і навичок іноземних студентів. Мовленнєвий змістовий складник визначає зміст роботи, скерованої на формування комунікативної компетентності іноземців і на реалізацію вторинної мовної особистості, що передбачає гармонійний розвиток умінь в основних видах мовленнєвої діяльності (аудіюванні, читанні, говорінні, письмі). Соціокультурний змістовий складник сфокусований на формуванні соціокультурної компетентності, яка створюється під час знайомства іноземців з особливостями культури України та мовленнєвої поведінки носіїв мови в різних комунікативних ситуаціях і передбачає розвиток умінь і навичок використовувати ці знання у спілкуванні [13, с. 141-142].

Реалізація змістових складників відображена в Сдиній типовій навчальній програмі 3 української мови для студентів-іноземців [5]. У програмі приділяється значна увага роботі над словом як одиницею морфологічного рівня мовної системи і на початковому, i на основному етапах навчання.

Загалом теоретичні засади навчання морфології розроблені такими вченими, як О. Біляєв, В. Горяний, Н. Грипас, В. Мельничайко, М. Плющ, М. Шкільник й ін. Сьогодні стрімкими темпами накопичується досвід методистів і вчителів щодо особливостей використання як традиційних, так і нестандартних підходів до вивчення морфології в школах нового типу (О. Горошкіна, В. Горяний, С. Караман й ін.). Активно досліджуються актуальні проблеми порівняльної методики викладання мов (А. Акішина, 
О. Біляєв, А. Богуш, В. Вагнер, Т. Вишнякова, Л. Вознюк, Є. Голобородько, О. Каган, В. Костомаров, Г. Михайловська, С. Ніколаєва, О. Падучева, Н. Пашківська, М. Пентилюк, К. Пучко, О. Хорошковська).

Лінгводидактика пропонує різноманітні методи та прийоми викладання української мови й іноземним студентам $[1 ; 2 ; 6 ; 8 ; 9 ; 10 ; 12]$. Актуальність досліджень визначається сучасними вимогами, спрямованими на вдосконалення національної системи освіти та розширення культурних зв'язків між країнами. Ці обставини певною мірою зумовлюють зміни соціальної мотивації засвоєння української мови як іноземної та необхідність оптимізації технологій іiі навчання, зокрема формування граматичної компетенції як складової комунікативної компетенції в різних видах мовленнєвої діяльності [11].

Методика мови має певний доробок 3 викладання теми «Дієслово» студентам-іноземцям $[4 ; 12 ; 14]$. При підготовці до занять 3 цієї теми можна використовувати значний досвід роботи з українськими школярами та студентами [6;7]. На жаль, комплексний порадник щодо вивчення дієслів 3 іноземними студентами відсутній. Недостатнє висвітлення питання в теорії та методиці навчання української мови як іноземної, низький рівень володіння основними дієслівними категоріями іноземних студентів спонукали до розробки низки взаємопов'язаних завдань, спрямованих на актуалізацію, поглиблення, узагальнення, систематизацію та закріплення знань студентів-іноземців 3 теми «Дієслово» на заняттях 3 української мови на I курсі. У статті пропонується фрагмент теми, а саме етап вивчення видових і часових форм дієслова.

Підгрунтя для оволодіння українською мовою формується під час навчання на підготовчому факультеті для іноземних громадян: студенти розрізнюють роди іменників, визначають число перших засвоєних лексем, утворюють форми роду присвійних займенників, засвоюють особові закінчення дієслів теперішнього часу, отримують уявлення про дієвідміни.

На початку I курсу знання студентів-іноземців актуалізуються, а згодом поглиблюються. Зокрема, на перших заняттях, присвячених вивченню дієслова, слід узагальнити й систематизувати засвоєне студентами про часові форми дієслів; роз'яснити відмінності в утворенні часових форм дієсловами доконаного й недоконаного видів; розвивати вміння та формувати навички правильного використання в мовленні часових форм дієслів. Пропонується таке обладнання: таблиці циклу «Час дієслів»; роздавальний матеріал граматичні вправи; перекладні й орфографічні словники.

Щодо роботи із теоретико-граматичним матеріалом зауважимо: протягом заняття всі визначення спершу озвучуються викладачем, згодом студенти читають їх з методичного посібника й відтворюють. Теоретичні відомості мають бути місткими, ілюструватися словами, зрозумілими студентам; не варто подавати приклади, що потребують тлумачення чи 
перекладу, оскільки це певним чином переобтяжує визначення та відволікає від розуміння його змісту. Нові слова бажано вводити при роботі з текстами, щоб іноземні студенти могли сприймати лексеми й 3 урахуванням їхніх синтаксичних функцій. Це полегшує студентаміноземцям подальше оперування новими словами.

На етапі актуалізації знань про дієслово студенти виконують різні види робіт. По-перше, повторюють визначення дієслова як частини мови: «Дієслова означають дію або стан предмета як процес і відповідають на питання: що робити? (співати, любити), що зробити? (заспівати, полюбити)». По-друге, міркують над запитанням «Чому ця частина мови називається саме «дієслово»? Далі шукають інфінітиви дієслів у текстах, опрацьованих на попередніх заняттях, або, наприклад, у таких народних прислів'ях: Умій пожартувати, та знай, коли перестати. Умій сказати, умій і мовчати. Життя прожити - не поле перейти. Щоб довго жити, треба працю любити. Добре того учити, хто хоче все знати.

Як зазначалося, знайомство іноземних студентів 3 категорією виду дієслів відбулося на заняттях 3 української мови на підготовчому факультеті. На І курсі варто повторити й поглибити ці відомості: «Дієслова бувають недоконаного й доконаного виду. Дієслова недоконаного виду не містять указівки на завершеність дії та відповідають на питання щзо робити? (писати, бігти, пити). Дієслова недоконаного виду вживаються в минулому (я писав, я писала), теперішньому (я пииу) і майбутньому (я писатиму, я буду писати) часі.

Дієслова доконаного виду означають дію із указівкою на іi завершеність i відповідають на питання щзо зробити? (написати, прибігти, випити). Дієслова доконаного виду вживаються лише в минулому (я написав, я написала) та майбутньому (я напишу) часі».

Після опрацювання теоретичного матеріалу студенти визначають види дієслів у видових парах: шукати - знайти, брати - взяти, заносити носити, робити - зробити, потанцюювати - танцюювати, відкривати відкрити, креслити - накреслити, намалювати - малювати, читати прочитати, написати - писати, приготувати - готувати, відпочивати відпочити, говорити - сказати, купити - купувати, відповісти відповідати, давати - дати. Слід запропонувати й таке завдання: Змініть видові форми дієслів: розуміти, сказати, дивитися, дарувати, зайти, телефонувати, переписати, запрошувати, закрити, переробити, забрати.

Актуалізацію знань про часи дієслів варто ілюструвати за допомогою таблиць. Таблиці важливі для опрацювання, узагальнення й систематизації граматичних відомостей; робота 3 таблицями увиразнює процес навчання, забезпечує глибше засвоєння матеріалу [12].

Цей етап роботи над часовими формами дієслів містить такий теоретичний матеріал: «Минулий час означає дію до моменту мовлення () Т. В. Мелкумова, 2013. 
(я раділа, він читав). Дієслова минулого часу змінюються за родами (він читав, вона читала, воно читало) й числами (я читав, ми читали)».

\begin{tabular}{|l|l|l|l|l|}
\hline \multicolumn{1}{|c|}{ інфінітив: } & креслити & накреслити & усміхатися & усміхнутися \\
\hline Чоловічий рід & креслив & накреслив & усміхався & усміхнувся \\
\hline Жіночий рід & креслила & накреслила & усміхалася & усміхнулася \\
\hline Середній рід & креслило & накреслило & усміхалося & усміхнулося \\
\hline Множина & креслили & накреслили & усміхалися & усміхнулися \\
\hline
\end{tabular}

Усно та письмово утворюють студенти форми минулого часу від дієслів кохати, переписати, розмовляти, почути, умиватися, умитися.

Форма теперішнього часу означає, що дія відбувається в момент мовлення (я радію; він читає). Дієслова теперішнього часу змінюються за числами (я читаю, ми читаємо) й особами (ти читаєш, він читає). За характером голосного в особовому закінченні дієслова теперішнього часу поділяються на першу та другу дієвідміни. До першої дієвідміни належать дієслова, які у формі III особи множини мають закінчення -ymb,-юmь: жити - живуть, поважати - поважають, малювати - малюють.

Зразки дієвідмінювання таких дієслів:

\begin{tabular}{|l|l|l|l|l|}
\hline \multicolumn{2}{|c|}{ інфінітив: } & читати & жити & усміхатися \\
\hline \multirow{4}{*}{ Однина } & я & читаю & живу & усміхаюся \\
\cline { 2 - 5 } & ти & читаєш & живеш & усміхаєшся \\
\cline { 2 - 5 } & він, вона, воно & читає & живе & усміхається \\
\hline \multirow{3}{*}{ Множина } & ми & читаєм(о) & живем(о) & усміхаємося \\
\cline { 2 - 5 } & ви, Ви & читаєте & живете & усміхаєтеся \\
\cline { 2 - 5 } & вони & читають & живуть & усміхаються \\
\hline
\end{tabular}

Усно та письмово утворюють студенти форми теперішнього часу від дієслів радіти, вивчати, малювати, умиватися.

До другої дієвідміни належать дієслова, які у формі III особи множини мають закінчення -ать, -ять: кричати - кричать, стояти стоять, мовчати - мовчать. Зразки дієвідмінювання:

\begin{tabular}{|l|l|l|l|l|}
\hline \multicolumn{2}{|c|}{ інфінітив: } & креслити & мовчати & дивитися \\
\hline \multirow{4}{*}{ Однина } & я & креслю & мовчу & дивлюся \\
\cline { 2 - 5 } & ти & креслиш & мовчиш & дивишся \\
\cline { 2 - 5 } & він, вона, воно & креслить & мовчить & дивиться \\
\hline \multirow{3}{*}{ Множина } & ми & креслим(о) & мовчим(о) & дивимося \\
\cline { 2 - 5 } & ви, Ви & креслите & мовчите & дивитеся \\
\cline { 2 - 5 } & вони & креслять & мовчать & дивляться \\
\hline
\end{tabular}

Усно та письмово утворюють студенти форми теперішнього часу від дієслів говорити, ходити (д $\rightarrow$ д), боятися.

Майбутній час означає дію, що відбудеться або відбуватиметься після процесу мовлення (я зрадію, я співатиму). Дієслова майбутнього часу змінюються за числами (вона радітиме, вони радітимуть) й особами (ти радітимеш, він радітиме). Зразки дієвідмінювання дієслів майбутнього часу недоконаного виду:

$$
-714-
$$

(C) Т. В. Мелкумова, 2013. 
МЕТОДИКА ВИКЛАДАННЯ МОВ

\begin{tabular}{|c|l|l|l|l|}
\hline \hline \multicolumn{2}{|c|}{ інфінітив: } & \multicolumn{2}{|c|}{ літати } & усміхатися \\
\hline \multirow{4}{*}{ Однина } & я & літатиму & буду літати & усміхатимуся \\
\cline { 2 - 5 } & ти & літатимеш & будеш літати & усміхатимешся \\
\cline { 2 - 5 } & він... & літатиме & буде літати & усміхатиметься \\
\hline \multirow{3}{*}{ Множина } & ми & літатимем $(\boldsymbol{о})$ & будемо літати & усміхатимемося \\
\cline { 2 - 5 } & ви, Ви & літатимете & будете літати & усміхатиметеся \\
\cline { 2 - 5 } & вони & літатимуть & будуть літати & усміхатимуться \\
\hline
\end{tabular}

Усно та письмово утворюють студенти форми майбутнього часу від дієслів недоконаного виду радіти, малювати, говорити, дивитися.

Зразки дієвідмінювання дієслів майбутнього часу доконаного виду:

\begin{tabular}{|l|l|l|l|l|}
\hline \multicolumn{2}{|c|}{ інфінітив: } & сказати & сходити & усміхнутися \\
\hline \multirow{4}{*}{ Однина } & я & скажу & схожу & усміхнуся \\
\cline { 2 - 5 } & ти & скажеш & сходиш & усміхнешся \\
\cline { 2 - 5 } & він, вона, воно & скаже & сходить & усміхнеться \\
\hline \multirow{3}{*}{ Множина } & ми & скажем(о) & сходим(о) & усміхнемося \\
\cline { 2 - 5 } & ви, Ви & скажете & сходите & усміхнетеся \\
\cline { 2 - 5 } & вони & скажуть & сходять & усміхнуться \\
\hline
\end{tabular}

Усно та письмово утворюють студенти форми майбутнього часу від дієслів доконаного виду зрадіти, намалювати, поговорити, подивитися. Можна запропонувати завдання: 1) Визначте дієслова теперішнього та майбутнього часу з-поміж таких: читала, читаю, читатиму; слухає, слухав, слухатиме; казатимуть, кажуть, казали; вилікував, вилікуєш; написали, напишемо; працюєте, працювали, будете праџювати; 2) Поставте дієслова у формах минулого та майбутнього часу, складіть із ними речення: святкувати, оглядати, вивчити, прочитати, купатися, нагадувати, лікувати, заїхати, ходити, пити; 3) Уставте на місці крапок дієслово потрібного виду в правильній формі: Той, хто багато ..., мало робить. Багато разів він ... зайти до мене, але до изього часу не зайшов. Нам ... організувати зустріч з ректором (обіияти - пообіияти). Ви ... для мене все, щзо могли (робити - зробити). Іноземні гості ... керівництву міста за приємну зустріч (дякувати - подякувати). ... у нього допомоги. Щоразу він ... мене перекласти на англійську мову те чи те слово. Він завжди ... мене купити свіжі газети (просити - попросити). Зовсім несподівано він ... мені (телефонувати - зателефонувати). - ... балет «Лісова пісня». Він вам сподобається. - Я ... ией балет декілька разів. -Коли ви ... цей балет останнього разу? - Минулого місяия (дивитися - подивитися).

Задля повторення, систематизації та закріплення відомостей про час, особу, число, рід дієслова варто виконати зі студентами комплексне завдання: Знайдіть дієслова; визначте: час (минулий, теперішній, майбутній), особу (I, II, III - для дієслів теперішнього та майбутнього часу), число (однина, множина), рід (для дієслів у формі однини минулого часу): Працюватимеш улітку - матимеш узимку. Час виховує людину. Ідеш - дорогу долаєи, сидиш - дні коротаєш. Кому добре, той С. Т. В. Мелкумова, 2013. 
співає, кому зле, той плаче. Діла говорять голосніме, як слова. Хто багато обіияє, той рідко слова дотримує.

Окремим етапом заняття $\epsilon$ індивідуальна робота студентів iз вправами за варіантами. Наприклад, I варіант може містити такі завдання: 1) Знайдіть дієслова жіночого роду: співав, принесла, говорила, прибігла, слухали, писав, читала, літало; 2) Утворіть усі форми минулого часу від дієслів писати, вчити; 3) Провідміняйте в теперішньому часі дієслово гуляти; 4) Визначте час, особу та число дієслова в реченні Сонечко ось-ось вийде з-за гори; 5) Утворіть усі можливі форми майбутнього часу від дієслова учити.

Варіант II: 1) Знайдіть дієслова чоловічого роду: Не той багато прожив, кому багато років, а той, хто багато зробив. Ще нічого не зробив, а вже відпочити сів; 2) Утворіть усі форми минулого часу від дієслів намалювати, вибачити; 3) Провідміняйте в теперішньому часі дієслово чекати; 4) Визначте час, особу та число дієслів у реченні Дивитимуся на сніс і мріятиму про літо; 5) Утворіть усі можливі форми майбутнього часу від дієслів телефонувати, вивчити.

Варіант III: 1) Визначте рід дієслова сnить. Утворіть форму чоловічого роду для дієслова принесла; 2) Утворіть усі форми минулого часу від дієслів креслити, читати; 3) Провідміняйте в теперішньому часі дієслово співати; 4) Визначте час, особу та число дієслова в реченні Я складу всі іспити добре; 5) Утворіть усі можливі форми майбутнього часу від дієслова купувати.

Варіант IV: 1) Поставте дієслова в тексті у формі минулого часу: Навесні кожне дерево співає свою пісню. Береза співає ніжну пісню. Дуб співає мужню пісню; 2) Утворіть усі форми минулого часу від дієслів малювати, накреслити; 3) Провідміняйте в теперішньому часі дієслово святкувати; 4) Визначте час, особу та число дієслів у реченні Будемо креслити й будемо малювати, бо хочемо графіку на «відмінно» знати; 5) Утворіть усі можливі форми майбутнього часу від дієслів учити, зателефонувати.

Домашнє завдання може складатися із двох завдань: 1) Запишіть дієслова 3 дужок у потрібній граматичній формі: Раніше я (любити) теніс, а зараз мені (подобатися) плавання. Учора моя колега (приїхати) $з$ Києва, але завтра вона вже (їати) у відрядження до Харкова. На тому тижні ми (відвідати) концерт, а на изьому (піти) до музею. Сьогодні ми (писати) важку контрольну роботу з математики, тому ввечері (відпочивати). Ти вже (ходити) до бібліотеки? Може, (сходити) разом? 2) Складіть розповідь про відвідування магазину, використовуючи дієслова иукати, знайти, вибирати, вибрати, давати, дати, купувати, купити в різних часових формах.

Наступним етапом у вивченні дієслів є виділення їх у зв’язному 
тексті, бажано за фахом, визначення при цьому граматичних категорій дієслів, а також виконання вправ трансформаційного характеру. Наприклад: Прочитайте текст; змініть часові форми дієслів: форму теперішнього часу дієслів замініть формою минулого часу. При виконанні подібних завдань робота над словом як структурним елементом морфологічного рівня мовної системи є дієвим чинником поглиблення знань і мовного розвитку іноземних студентів. Навчальний матеріал для занять 3 української мови варто поєднувати з матеріалом інших вузівських дисциплін, звертаючи при цьому увагу на засвоєння змістового компонента.

\section{Література}

1. Азарова Л. Є. Українська мова для слухачів-іноземців підготовчого відділення : збірник вправ і завдань : [навч. посібник] / Л. С. Азарова, І. Є. Зозуля, Л. В. Солодар. Вінниця : ВНТУ, 2010. - $121 \mathrm{c.}$

2. Бахтіярова Х. Ш. Українська мова : практичний курс для іноземців : [посібник для слухачів підготовчих відділень і факультетів] / Х. Ш. Бахтіярова, С. С. Лукашевич, I. 3. Майданюк й ін. - Тернопіль : Укрмедкнига, 1999. - 320 с.

3. Білецька О. Українська мова : комплексна підготовка до зовнішнього незалежного оцінювання / О. Білецька, І. Житар, Т. Матвійчук. - Тернопіль: Підручники і посібники, 2013. $-576 \mathrm{c}$.

4. Дерба С. М. Вивчення іноземними студентами українського дієслівного керування / С. М. Дерба // Мовні і концептуальні картини світу. - 2011. - Вип. 36. - С. 255-260.

5. Єдина типова навчальна програма 3 української мови для студентів-іноземців основних факультетів нефілологічного профілю вищих навчальних закладів України III-IV рівнів акредитації / Уклад. : Л. І. Дзюбенко, В. В. Дубічинський, С. А. Чезганов та ін. ; за ред. О. Н. Тростинської, Н. І. Ушакової. - К. : НТУУ «КПІ», 2009. - 52 с.

6. Зайченко Н. Ф. Практичний курс української мови для іноземців : усне мовлення / Н. Ф. Зайченко, С. А. Воробйова. - К. : Знання України, 2005. - 324 с.

7. Караман С. О. Практикум з методики навчання української мови / С. О. Караман, О. В. Караман, О. М. Горошкіна й ін. ; за ред. М. І. Пентилюк. - К. : Ленвіт, 2003. - 302 с.

8. Коньок О. П. Українська мова : навчальні матеріали для студентів-іноземців І курсу / О. П. Коньок. - Суми : Вид-во СумДУ, 2009. - 103 с.

9. Лисенко Н. О. Українська мова для іноземних студентів : [навч. посібник] / Н. О. Лисенко, Р. М. Кривко, С. І. Світлична, Т. П. Цапко ; за ред. С. М. Смоленського. К. : Центр учбової літератури, 2010. -240 с.

10. Методика навчання української мови : [підручник он-лайн]. - Режим доступу : http://subject.com.ua/ukrmova/method/index.html.

11. Ніколаєнко В. В. Формування російськомовної граматичної компетенції англомовних студентів-іноземців на початковому етапі навчання у вищій школі (на матеріалі дієслівних категорій) : автореф. дис. ... канд. пед. наук: 13.00 .02 / В. В. Ніколаєнко. - Херсон, 2004. - 20 с.

12. Тишковець М. Використання таблиць у вивченні української мови як іноземної / Марія Тишковець // Теорія і практика викладання української мови як іноземної. - 2008. - Вип. 3. - С. 262-268.

13. Ушакова Н. І. Концепція мовної підготовки іноземців у ВНЗ України / Н. І. Ушакова, В.В.Дубічинський, О.М.Тростинська // Викладання мов у вищих навчальних закладах освіти. - 2011. - Вип. 19. - С. 136-146.

14. Шевченко М. В. Парадигматичні особливості українських дієслів руху у світлі лінгводидактики / М. В. Шевченко // Компоративні дослідження слов'янських мов і літератур. - 2011. - Вип. 16. - С. 192-199. 